\title{
Quantification of ruminal microbiota and production of methane and carbonic dioxide from diets with inclusion of glycerin
}

\author{
[Quantificação da microbiota ruminal e produção de metano e gás carbônico de \\ dietas com inclusão de glicerina] \\ V.C. Santos ${ }^{1}$, J.M.B. Ezequiel ${ }^{1}$, A.C. Homem Junior ${ }^{l}$, R.S.B. Pinheiro ${ }^{2}$ \\ ${ }^{l}$ Universidade Estadual Paulista "Júlio de Mesquita Filho"- FCAV-UNESP - Jaboticabal, SP \\ ${ }^{2}$ Universidade Estadual Paulista "Júlio de Mesquita Filho"- FEIS-UNESP - Ilha Solteira, SP
}

\begin{abstract}
The aim of this study was to quantify the liquid-associated bacteria and protozoa of the rumen and to evaluate the potential of in vitro production of gases $\mathrm{CH}_{4}$ and $\mathrm{CO}_{2}$ of diets with inclusion of glycerin for sheep. Two diets were formulated with a roughage:concentrate ratio of 20:80, according to the presence or absence of glycerin: G0 - control, without glycerin; and G10 - 10\% glycerin as part of the concentrate. To quantify the liquid-associated bacteria and protozoa from the rumen and production of $\mathrm{CH}_{4}$ and $\mathrm{CO}_{2}$ gases, a completely randomized design was used. The diets had no effect $(\mathrm{P}>0.05)$ on production and composition of liquid-associated protozoa and bacteria from the rumen of lambs. Likewise, a $(\mathrm{P}>0.05)$ diet effect was not observed on production of $\mathrm{CH}_{4}$ and $\mathrm{CO}_{2}$ in vitro, which presented average concentrations of $24.55 \mathrm{~mL} / \mathrm{g}$ MS and $51.52 \mathrm{~mL} / \mathrm{g}$ MS, respectively. The use of $10 \%$ glycerin did not alter production or composition of ruminal microflora, and moreover, did not negatively impact the production of $\mathrm{CH}_{4}$ and $\mathrm{CO}_{2}$ gases in vitro.
\end{abstract}

Keywords: sheep, bacteria, gases, nitrogen, protozoa

\section{RESUMO}

Objetivou-se com este estudo quantificar as bactérias e protozoários líquido-associados do rúmen e avaliar o potencial de produção dos gases $\mathrm{CH}_{4}$ e $\mathrm{CO}_{2}$ in vitro de dietas com inclusão de glicerina para ovinos. Duas dietas foram formuladas, na proporção volumoso:concentrado de 20:80, conforme a presença ou ausência de glicerina: G0 - controle sem glicerina, G10 - 10\% glicerina como parte do concentrado. Para a quantificação das bactérias e protozoários líquido-associados do rúmen e produção dos gases $\mathrm{CH}_{4}$ e $\mathrm{CO}_{2}$, utilizou-se o delineamento inteiramente ao acaso. Não foi observado efeito de dieta $(P>0,05)$ sobre a produção e composição de protozoários e bactérias líquido-associados do rúmen de cordeiros. Da mesma forma, não houve efeito de dieta $(\mathrm{P}>0,05)$ sobre a produção de $\mathrm{CH}_{4}$ e $\mathrm{CO}_{2}$ in vitro, os quais apresentaram concentrações médias de $24,55 \mathrm{~mL} / \mathrm{g} M S$ e $51,52 \mathrm{~mL} / \mathrm{g} M S$, respectivamente. $O$ uso de $10 \%$ glicerina não altera a produção ou composição da microflora ruminal, e também não impacta negativamente a produção dos gases $\mathrm{CH}_{4}$ e $\mathrm{CO}_{2}$ in vitro.

Palavras-chave: ovino, bactéria, gases, nitrogênio

\section{INTRODUCTION}

The use of glycerin in diets for ruminants is not recent; however, this interest has been renewed due to its increased availability and favorable price. Although the effects of glycerin in the feeding of ruminants either as an energy supplement or as a substitute of corn (Parsons et al., 2009) on animal performance are welldocumented, little is known about its effects on the fermentation pattern and on rumen microorganisms. Evaluating the quantity and quality of ruminal microorganisms is extremely important for animal nutrition, as growth and milk-yield prediction models require estimates of the microbial protein synthesis.

Recebido em 9 de abril de 2013

Aceito em 30 de julho de 2014

E-mail: vivianecorreasantos@gmail.com 
Along with the maximization of the efficiency of microbial protein synthesis, the optimization of rumen fermentation has been the target of many scientists, as well as utilization of energy by the rumen, maximization of nitrogen use by the rumen bacteria and the reduction of methane and ammonia losses, which are some of the goals of nutritionists to efficiently improve animal performance (Eugène et al., 2004). For this purpose, it is necessary to study the microorganisms' populations present in the ruminal environment and the factors that result from modifications in their quality and functionality.

The $\mathrm{CH} 4$ emission by ruminants depends on several factors such as animal species, composition and amount of concentrate in the diet, level of intake, type of carbohydrate in the diet, feed processing, addition of lipids or ionophores in the diet and change in the ruminal microflora (Morgado et al., 2013).

The differences in the nutritional composition of feedstuffs may result in different fermentation patterns in ruminants, which cause the end products of microbial fermentation - especially acetic, propionic and butyric fatty acids - to be at different proportions; these products represent an important source of energy for the ruminant metabolism. Along with these fermentation processes there is production of $\mathrm{CH}_{4}$ and $\mathrm{CO}_{2}$; the production of $\mathrm{CH}_{4}$ is influenced mainly by the carbohydrates in the diet. Production of $\mathrm{CH}_{4}$ represents loss of dietary energy consumed by ruminants, in addition to contributing to global warming. Strategies such as increasing the level of grains in the diet, including lipids and supplementing the diet with ionophores are highly likely to reduce emissions of rumen $\mathrm{CH}_{4}$, in addition to improving production efficiency (Beauchemin et al., 2008). According to (Pereira et al., 2006) little is known about the emissive behavior of gaseous pollutants from sheep, since the emphasis has been given to differences between emissive components of the diet. Thus, the aim of this study was to quantify the liquidassociated bacteria and protozoa of the rumen and to evaluate the potential of in vitro production of gases $\mathrm{CH}_{4}$ and $\mathrm{CO}_{2}$ of diets with inclusion of glycerin.

\section{MATERIAL AND METHODS}

The experiment was carried out at the Animal Unit for Digestive and Metabolic Research of the Department of Animal Science of the Faculty of Agricultural and Veterinary Sciences of UNESP, Campus Jaboticabal-São Paulo, Brazil.

Two diets (Table 1) were formulated (NRC, 2006) with a roughage:concentrate ratio of 20:80, using chopped Cynodon spp. as a source of roughage. The concentrate feed was composed by ground corn grain, soybean meal, limestone, mineral supplement, and inclusion or not of glycerin according to the diets: G0 - control, without glycerin; and G10 - 10\% glycerin as part of the concentrate. The glycerin was extracted from soybean oil, which contains $83 \%$ glycerol, $11 \%$ water, $6 \%$ salts (of which $99 \%$ is $\mathrm{NaCl}$ ) and $0.01 \%$ methanol (Caramuru Alimentos Ltda.).

Table 1. Chemical composition of experimental diets, with inclusion (G10) or not (G0) of glycerin, for sheep

\begin{tabular}{|c|c|c|}
\hline & \multicolumn{2}{|c|}{ Diets (\% of DM) } \\
\hline Ingredients & G0 ${ }^{1}$ & $\mathrm{G}^{2} 0^{2}$ \\
\hline Tifton hay & 20.00 & 20.00 \\
\hline Corn grain & 55.40 & 45.40 \\
\hline Glycerin & - & 10.00 \\
\hline Soybean meal & 23.00 & 23.00 \\
\hline Limestone & 0.60 & 0.60 \\
\hline Mineral supplement* & 1.00 & 1.00 \\
\hline \multirow[t]{2}{*}{ Total } & 100.00 & 100.00 \\
\hline & \multicolumn{2}{|c|}{ Composition (\% of DM) } \\
\hline Dry matter & 89.59 & 87.81 \\
\hline Ash & 5.05 & 5.27 \\
\hline Organic matter & 84.54 & 82.54 \\
\hline Ether extract & 3.19 & 3.15 \\
\hline Crude protein & 20.70 & 20.00 \\
\hline $\begin{array}{l}\text { Metabolizable energy } \\
\text { (Mcal/kg DM)** }\end{array}$ & 3.00 & 3.00 \\
\hline \multicolumn{3}{|c|}{$\begin{array}{l}{ }^{1} \mathrm{G} 0 \text { : control without glycerin; }{ }^{2} \mathrm{G} 10 \text { : formulated with } \\
10 \% \text { glycerin. } \\
{ }^{*} \text { Commercial mineral supplement for sheep }(\mathrm{P}=60 \mathrm{~g} \text {; } \\
\mathrm{Ca}=110 \mathrm{~g} ; \mathrm{Na}=195 \mathrm{~g} ; \mathrm{Cl}=300 \mathrm{~g} ; \mathrm{Mg}=10 \mathrm{~g} ; \mathrm{S}=25 \mathrm{mg} \text {; } \\
\mathrm{Zn}=4,000 \mathrm{mg} ; \mathrm{Cu}=600 \mathrm{mg} ; \mathrm{Mn}=600 \mathrm{mg} ; \mathrm{Fe}=1,200 \mathrm{mg} ; \\
\mathrm{Co}=100 \mathrm{mg} ; \mathrm{I}=180 \mathrm{mg} ; \mathrm{Se}=12 \mathrm{mg} ; \mathrm{Fl} \quad(\text { maximum})= \\
0.60 \mathrm{mg}) \text {. } \\
\text { ** EM }=12,71-0,0108(\mathrm{ADF})+0,0262(\mathrm{EE}) \text {. } \\
\text { ** de Boever } \text { et al. }(1999) \text {, values obtained in } \mathrm{MJ} / \mathrm{kg} \\
\text { DM and transformed to Mcal } / \mathrm{kg} \mathrm{DM}\end{array}$} \\
\hline
\end{tabular}

For quantification of ruminal microbiota 40 uncastrated male Santa Inês $\times$ Dorper weaned lambs with an average age of 80 days and weight 
of $21 \pm 2.3 \mathrm{~kg}$ were utilized. Animals were identified and distributed in a completely randomized design with 20 replications.

Diets were fed twice daily (08h00 and 16h00) and animals had free access to water during the entire experimental period.

When animals reached approximately $33 \mathrm{~kg}$ of weight, they were weighed and fed only water for 16 hours. The animals were stunned by a bolt pistol without penetration. Animals were bled through their jugular vein and carotid arteries immediately after being stunned.

After the lambs were slaughtered, their gastrointestinal tract was emptied and approximately $200 \mathrm{~g}$ of samples of the ruminal content were collected manually. To separate the liquid phase from the solid phase the ruminal content was initially filtrated in a nylon filter with a pore size of $100 \mu \mathrm{m}$ for subsequent separation and quantification of liquid-associated bacteria and protozoa according to the methodology of Martin et al. (1994).

To identify the liquid phase, the rumen fluid (700 $\mathrm{mL}$ ) was diluted in an equal volume of saline solution (Coleman, 1978) preheated at $39^{\circ} \mathrm{C}$. This final solution was incubated from 30 to 60 minutes at $39^{\circ} \mathrm{C}$. Glucose was added $(1 \mathrm{~g} / \mathrm{L})$ five minutes before the end of incubation so as to separate the protozoa from the rest of the rumen content and to optimize flocculation.

The protozoan pellet was recovered by centrifuging the clarified fluid at $1,000 \times \mathrm{g}$ for 10 minutes, at room temperature. This pellet was later washed with a saline solution in a nylon filter with pore size of $20 \mu \mathrm{m}$ ( 1 liter, at $39^{\circ} \mathrm{C}$ ), to minimize contamination by bacteria and residue of feeds. Liquid-associated bacteria (LAB) were obtained by centrifuging the protozoa-free supernatant fluid at $15,000 \times \mathrm{g}$ for 20 minutes at $4^{\circ} \mathrm{C}$. Subsequently, samples were lyophilized and analyzed for the contents of nitrogen $(\mathrm{N})$, dry matter (DM) and mineral matter (MM), and the organic matter $(\mathrm{OM})$ content was estimated.

For production of gases $\mathrm{CH}_{4}$ and $\mathrm{CO}_{2}$ four Santa Inês $\mathrm{x}$ Dorper sheep with mean body weight of $47.3 \mathrm{~kg}$, cannulated in the rumen were used, and measurements of production of $\mathrm{CH}_{4}$ and $\mathrm{CO}_{2}$ gases were done using Incubater SHAKER SL
222 consisting of three stages: 1 - Preparation of the sample: prior to feeding four rumencannulated sheep, we collected approximately $500 \mathrm{~mL}$ of the rumen content, filtered the material through a nylon fabric $(100 \mu \mathrm{m})$ and homogenized it. In erlenmeyers with a capacity of $250 \mathrm{~mL}, 150 \mathrm{~mL}$ of ruminal fluid were placed added of $1.56 \mathrm{~g} \mathrm{DM}$ of the diets studied ground to $1 \mathrm{~mm}$, in order were previously added so as to keep the ratio of $1 \mathrm{~g}$ sample: $8 \mathrm{~mL}$ rumen fluid. 2 Production and storage of gases: the erlenmeyers with samples and rumen fluid were closed with stoppers and kept in a water bath for 12 hours at $39^{\circ} \mathrm{C}$ in a dark room, and the gases produced were led by capillary system of silicone and stored in a proper plastic container with internal volume of $600 \mathrm{~mL}$. Such collectors were immersed in water enabling measurement of total gases by water displacement therein. 3 Quantitative and qualitative analysis of the gas produced: an aliquot was directly collected from the erlenmeyers with the aid of a $1 \mathrm{~mL}$ syringe, then immediately injected in a gas chromatograph (Trace GC Ultra, Thermo Scientific $^{\Theta}$ ) metanador and equipped with a flame ionization detector, using argon as carrier gas with a flow of $25 \mathrm{~mL}$ per minute, and the oven temperature was set to $70^{\circ} \mathrm{C}$. The calibration was performed with a mixture of gases $\mathrm{CH}_{4}$ and $\mathrm{CO}_{2}$. The peak areas were integrated with software Chromquest 5.0. The total gas produced was measured by displacement of collectors, immersed in water after 12 hours of fermentation.

To quantify the liquid-associated bacteria and protozoa from the rumen production of methane and carbonic gases we used a completely randomized design with 20 replications per diet for quantification of ruminal microbiota and 15 replications per diet for production of gases $\mathrm{CH}_{4}$ and $\mathrm{CO}_{2}$. Data were analyzed utilizing the PROC GLM procedure on the Statistical Analysis System (SAS, 2001).

\section{RESULTS AND DISCUSSION}

The diets had no effect $(\mathrm{P}>0.05)$ on production and composition of liquid-associated protozoa from the rumen of lambs fed diets with/without glycerin. Although there were no statistical differences, dry matter, organic matter and nitrogen productions were respectively $21.20 \%$, 
$23.14 \%$ and $27.54 \%$ lower than the average of the diet with inclusion of glycerin (Table 2).

The average chemical composition of protozoa obtained by Martin et al. (1994) in organic matter and nitrogen were respectively 89.5 and $5.1 \%$ and Ezequiel et al. (2002) found 75.2 and $4.9 \%$ organic matter and nitrogen, respectively. In the present study, protozoa showed on average $49.7 \%$ organic matter and $9.7 \%$ nitrogen. The organic matter was lower than the values obtained in the aforementioned studies and the nitrogen values were above them; this can be explained by the differences between the diets evaluated and the presence of saline solution, which resulted in a higher mineral matter content in the samples. This hypothesis was also mentioned by Mendes et al. (2006) as the cause of the large variation in the microbial organic matter values found in the literature.

No effect of diets $(\mathrm{P}>0.05)$ was observed on production and composition of liquid-associated bacteria from the rumen of lambs fed diets with/without glycerin. Although they showed no statistical differences, productions of dry matter, organic matter and nitrogen were respectively $8.00,8.58$ and $13.68 \%$ below the average of the diet with inclusion of glycerin (Table 2).

Table 2. Production and composition of liquid-associated protozoa and bacteria in the rumen of lambs fed with glycerin

\begin{tabular}{|c|c|c|c|c|}
\hline \multirow[b]{2}{*}{ Variables } & \multicolumn{2}{|c|}{ Diets } & \multirow[b]{2}{*}{ CV (\%) } & \multirow[b]{2}{*}{$\mathrm{P}$ value } \\
\hline & $\mathrm{G}^{1}$ & $\mathrm{G} 10^{2}$ & & \\
\hline \multicolumn{5}{|c|}{ Protozoa } \\
\hline Dry matter $(\mathrm{mg} / \mathrm{L})$ & 576.10 & 731.00 & 57.12 & 0.3763 \\
\hline Organic matter $(\%)$ & 50.62 & 48.75 & 16.69 & 0.6822 \\
\hline Organic matter $(\mathrm{mg} / \mathrm{L})$ & 294.70 & 383.40 & 74.89 & 0.4547 \\
\hline Nitrogen $(\% \mathrm{MO})$ & 9.25 & 10.10 & 22.23 & 0.3964 \\
\hline Nitrogen (mg/L) & 52.71 & 72.74 & 55.39 & 0.2228 \\
\hline \multicolumn{5}{|c|}{ Bacteria } \\
\hline Dry matter (mg/L) & 1069.70 & 1162.80 & 47.87 & 0.7015 \\
\hline Organic matter $(\%)$ & 73.24 & 72.72 & 4.83 & 0.7462 \\
\hline Organic matter (mg/L) & 785.30 & 859.00 & 50.66 & 0.6971 \\
\hline Nitrogen $(\% \mathrm{MO})$ & 10.38 & 10.87 & 14.44 & 0.4834 \\
\hline Nitrogen (mg/L) & 112.10 & 129.86 & 54.88 & 0.5571 \\
\hline
\end{tabular}

The average organic matter (\%DM) and nitrogen $(\% \mathrm{OM})$ contents of the bacterial fractions associated with the rumen fluid obtained in this study were 72.98 and $10.63 \%$, respectively. Homem Júnior et al. (2010) found mean organic matter values of $81.1 \%$ and $11.3 \%$ nitrogen in bacteria from the rumen fluid and Ezequiel et al. (2002) reported organic matter and nitrogen contents of $81.6 \%$ and $6.7 \%$ for the liquidassociated bacteria. The organic matter content found by these authors was higher than those obtained in our experiment. However, Martin et al. (1994) reported organic matter contents of bacteria from the liquid phase within the range from 60.3 to $64.7 \%$ and Mendes et al. (2006) obtained an average $57.0 \%$ organic matter, and these numbers are lower than those found in our study.
The absence of a significant effect on nitrogen contents should be taken into account, since most of the nitrogen that the animal uses is of microbial origin, and if the contents decreased with inclusion of glycerin, this decrease would probably cause problems because of the low nitrogen availability. Ezequiel et al. (2002) reported nitrogen contents of $6.7 \%$ in the liquidassociated fraction, which is different from the present study, and may be linked to the fact that the protein content of the diets in our study was higher.

Preliminary research indicates that glycerin affects the growth of some rumen bacteria. Abo El-Nor et al. (2010) evaluated the effect of replacing corn with glycerin at concentrations of $0,36,72$ and $108 \mathrm{~g} / \mathrm{kg} \mathrm{DM}$ in a diet for Holstein 
cows on rumen fermentation and observed a decrease in the concentration of DNA of bacteria Butyrivibrio fibrosolvens and Selenomonas ruminantium as the glycerin content in the diet was elevated. However, this mechanism still isn't elucidated, because the sensitivity of microorganisms may vary according to the level of glycerin inclusion in the diet. Moreover, glycerin can also interfere with the bacterial adhesion to food particles.

In the literature there are descriptions of large variations in the chemical composition of rumen microorganisms (Homem Júnior et al., 2010). Variations depend on the methodology of isolation adopted and on the several diets that can be formulated and which modify the supply of fermentable substrate and consequently microbial growth and its composition.

Diets did not differ $(\mathrm{P}>0.05)$ as to the production of $\mathrm{CH}_{4}$ and $\mathrm{CO}_{2}$ produced in vitro (Table 3 ). This demonstrates that inclusion of $10 \%$ glycerin does not change the production of $\mathrm{CH}_{4}$ and $\mathrm{CO}_{2}$, which disagrees with the results of Van Cleef et al. (2012), who evaluated the in vitro production of greenhouse gases using different concentrations of crude glycerin $(0,7.5,15,22.5$ and $30 \%$ ) in diets for Nellore cattle and observed that regardless of the concentration, crude glycerin caused reduction in $\mathrm{CH}_{4}$ and $\mathrm{CO}_{2}$ during 12 hours of incubation.

The mean value obtained for methane production is higher than those reported by Avila-Stagno et al. (2013) from 9.6 to $12.3 \mathrm{~mL} / \mathrm{g} \mathrm{DM}$ intake, using the methodology of respirometric chambers to determine the methane production of lambs fed diets with increasing levels of 0,7 , 14 and $21 \%$ glycerol. The highest methane production observed in this study may be due to high concentrate (80\%), which correlates positively with the total gas production (Lee et al., 2011), which may also explain the lack of effect the addition of glycerin has on the reduction of methane. According to Lee et al. (2011) methane production of in vitro alfalfa was 17.9 , while corn was $29.6 \mathrm{~mL} / \mathrm{g}$ DM incubated, the latter being very close to the value obtained in this study, in which a high proportion of used concentrate was used.

According to some authors (Abo El-Nor et al., 2010; Ávila et al., 2011), glycerin has a ruminal fermentation characteristic of formation of propionic acid and reduction in acetate: propionate ratio, which would lead to reduction in the production of methane removal of $\mathrm{H}_{2}$ from the middle, but it is possible that on a diet with high concentrate this effect is not as pronounced as on a diet with a high proportion of roughage feed (Lee et al., 2011).

Evaluating the in vitro production of diets containing $12 \%$ crude glycerin in replacement of barley, Ávila et al. (2011) did not observe any effect on methane production. Also, incubating a few ingredients with and without glycerin in vitro for up to 48 hours, Lee et al. (2011) did not observe alterations in methane production in their study.

Table 3. In vitro production of methane $\left(\mathrm{CH}_{4}\right)$ and carbon dioxide $\left(\mathrm{CO}_{2}\right)$ of diets including glycerin

\begin{tabular}{lcccc} 
& \multicolumn{2}{l}{ Diets } & & \\
\cline { 2 - 3 } Variable & $\mathrm{G} 0^{1}$ & $\mathrm{G} 10^{2}$ & $\mathrm{CV}(\%)$ & $\mathrm{P}$ \\
\hline $\mathrm{CH}_{4}$ (mL/g MS) & 24,93 & 24,16 & 6,76 & 0,3114 \\
$\mathrm{CO}_{2}$ (mL/g MS) & 52,65 & 50,39 & 17,69 & 0,5876 \\
\hline
\end{tabular}

${ }^{1} \mathrm{G} 0$ : control without glycerin; ${ }^{2} \mathrm{G} 10$ : formulated with $10 \%$ glycerin.

$\mathrm{CV}=$ coefficient of variation

$\mathrm{P}=$ probability

\section{CONCLUSIONS}

The use of glycerin did not affect production or composition of liquid-associated bacteria and protozoa from the rumen. The in vitro production of gases $\mathrm{CH}_{4}$ and $\mathrm{CO}_{2}$ does not change with the inclusion of $10 \%$ crude glycerin in the diet.

\section{ACKNOWLEDGEMENTS}

The authors would like to thank the Foundation for Research of São Paulo State (FAPESP) for funding the research and Carmuru Fodd Ltda for providing glycerin. 


\section{REFERENCES}

ABO EL-NOR, S.A.; ABUGHAZALEH, A.A.; POTU, R.B. et al. Effects of differing levels of glycerol on rumen fermentation and bacteria. Anim. Feed Sci. Technol., v.162, p.99-105, 2010.

ÁVILA, J.S.; CHAVES, A.V.; HERNANDESCALVA, M. et al. Effects of replacing barley grain in feedlot diets with increasing level of glycerol on in vitro fermentation and methane production. Anim. Feed Sci. Technol., v.166-167, p.265-268, 2011.

AVILA-STAGNO, J.; CHAVES, A.V.; HE, M.L. et al. Effects of increasing concentrations of glycerol in concentrate diets on nutrient digestibility, methane emissions, growth, fatty acid profiles, and carcass traits of lambs. J. of Anim. Sci., v.91, p.829-837, 2012.

BEAUCHEMIN, K.A.; KREUZER, M.; O'MARA, F. et al. Nutritional management for enteric methane abatement: A review. Aust. J. of Experim. Agricul., v.48, p.21-27, 2008.

COLEMAN, G.S. Rumen entodinomorph protozoa. In: TAYLOR, A.E.R.; BAKER, J.R. (Ed) Methods of Cultivating Parasites in Vitro. London: Academic Press, 1978. p. 39-54.

DE BOEVER, J.L.; COTTYN, B.G.; DE BRABANDER, D.L. et al. Equations to predict digestibility and energy value of grass silages, maize silages, grass hays, compound feeds and raw materials for cattle. Nutrition Abstracts and Reviews, Series B , v.69, p.835-850, 1999.

EUGÈNE, M.; ARCHIMÈDE, H.; SAUVANT, D. Quantitative meta analysis on the effects of defaunation of the rumen on growth, intake and digestion in ruminants. Livest. Produc. Sci., v.85, p.81-87, 2004.

EZEQUIEL, J.M.B.; MELÍCIO, S.P.L.; SANCANARI, J.B.D. et al. Quantificação das bactérias sólido-aderidas, bactérias e protozoários líquido associados do rúmen de bovinos jovens alimentados com amireia. Rev. Bras. Zootec., v.31, p.707-715, 2002.

HOMEM JUNIOR, A.C.; EZEQUIEL, J.M.B.; FÁVARO, V.R. et al. Fermentação ruminal de ovinos alimentados com alto concentrado e grãos de girassol ou gordura protegida. Arq. Bras. Med. Vet. Zootec., v.62, p.144-153, 2010.

LEE, S.Y.; LEE, S.M.; CHO, Y.B. et al. Glycerol as a feed supplement for ruminants: in vitro fermentation characteristics and methane production. Anim. Feed Sci. Technol., v.166-167, p.269-274, 2011.

MARTIN, C.; WILLIANS, A.G.; MICHALETDOREAU, B. Isolation and characteristics of the protozoal and bacterial fractions from bovine ruminal contents. J. Anim. Sci., v.72, p.29622968, 1994.

MENDES, A.R.; EZEQUIEL, J.M.B.; GALATI, R.L. et al. Cinética digestiva e eficiência de síntese de proteína microbiana em novilhos alimentados com farelo de girassol e diferentes fontes energéticas. Rev. Bras. Zootec., v.35, p.264-274, 2006.

MORGADO, E.S.; EZEQUIEL, J.M.B.; HOMEM JUNIOR, A.C. et al. Potencial de produção de gás metano e dióxido de carbono in vitro dos ingredientes utilizados em dietas para ovinos. Cienc. Anim. Bras., v.14, p.413-417, 2013.

NATIONAL Research Council-NRC. Nutrient requirements of small ruminants. Washington: National Academy. 2006. 362p.

PARSONS, G.L.; SHELOR, M.K.; DROUILLARD, J.S. Performance and carcass traits of finishing heifers fed crude glycerin. $J$. Anim. Sci., v.87, p.653-657, 2009.

PEREIRA, E.M.O; EZEQUIEL, J.M.B.; FEITOSA, J. Determinação in vitro do potencial de produção de metano e dióxido de carbono de líquido ruminal proveniente de bovinos de diferentes categorias. Arch. Latinoam. Produc. Anim., v.14, p.120-127, 2006.

SAS Institute inc. Technical Report: SAS/STAT. Release 8.2. Cary, 2001.

VAN CLEEF, E.H.C.B.; EZEQUIEL, J.M.B.; D'ÁUREA, A.P. et al. Effects crude glycerin on in vitro gas production and VFA profiles in Nellore feedlot steers. J. Anim. Sci., v.90, p.337, 2012. 